\title{
The Ras-related small GTPases RalA and RalB regulate cellular survival after ionizing radiation
}

\author{
Ambrose R. Kidd III, Ph.D. ${ }^{1}$, Jared L. Snider, Ph.D. ${ }^{1}$, Timothy D. Martin, B.S. ${ }^{2}$, Sarah F. \\ Graboski, M.D. ${ }^{3}$, Channing J. Der, Ph.D. ${ }^{1,2}$, and Adrienne D. Cox, Ph.D. 1,2,3 \\ ${ }^{1}$ Lineberger Comprehensive Cancer Center, University of North Carolina at Chapel Hill, Chapel \\ Hill, North Carolina 27599 \\ ${ }^{2}$ Department of Pharmacology, University of North Carolina at Chapel Hill, Chapel Hill, North \\ Carolina 27599
}

${ }^{3}$ Department of Radiation Oncology, University of North Carolina at Chapel Hill, Chapel Hill, North Carolina 27599

\section{Abstract}

Purpose-Oncogenic activation of Ras renders cancer cells resistant to ionizing radiation (IR), but the mechanisms have not been fully characterized. The Ras-like small GTPases, RalA and RalB, are downstream effectors of Ras function and are critical for both tumor growth and survival. The Ral effector RalBP1/RLIP76 mediates survival of mice after whole body irradiation but the role of the Ral GTPases themselves in response to IR is unknown. We have investigated the role of RalA and RalB in cellular responses to IR.

Methods and Materials-RalA, RalB and their major effectors RalBP1 and Sec5 were knocked down by stable expression of shRNAs in the K-Ras-dependent pancreatic cancer-derived cell line MIA PaCa-2. Radiation responses were measured by standard clonogenic survival assays for reproductive survival, $\gamma \mathrm{H} 2 \mathrm{AX}$ expression for double-strand DNA breaks (DSBs) and PARP cleavage for apoptosis.

Results-Knockdown of K-Ras, RalA or RalB reduced colony-forming ability post-IR and knockdown of either Ral isoform decreased the rate of DSB repair post-IR. However, knockdown of RalB, but not RalA, increased cell death. Surprisingly, neither RalBP1 nor Sec5 suppression affected colony formation post-IR.

Conclusions-Both RalA and RalB contribute to K-Ras-dependent IR resistance of MIA $\mathrm{PaCa}-2$ cells. Sensitization due to suppressed Ral expression is likely due in part to decreased efficiency of DNA repair (RalA and RalB) and increased susceptibility to apoptosis (RalB). Ralmediated radioresistance does not depend on either RalBP1 or the exocyst complex, the two bestcharacterized Ral effectors, and instead may utilize an atypical or novel effector.

\footnotetext{
(C) 2010 Elsevier Inc. All rights reserved.

Corresponding author: Adrienne D. Cox, PhD Department of Radiation Oncology Lineberger Comprehensive Cancer Center University of North Carolina at Chapel Hill Chapel Hill, NC 27599-7295 919-966-7712 (phone) 919-966-9763 (fax) adrienne_cox@med.unc.edu.

Publisher's Disclaimer: This is a PDF file of an unedited manuscript that has been accepted for publication. As a service to our customers we are providing this early version of the manuscript. The manuscript will undergo copyediting, typesetting, and review of the resulting proof before it is published in its final citable form. Please note that during the production process errors may be discovered which could affect the content, and all legal disclaimers that apply to the journal pertain.

Conflict of Interest Notification

The authors declare that they have no conflicts of interest.
} 


\section{Keywords}

RalA; RalB; RalBP1; pancreatic cancer; ionizing radiation

\section{Introduction}

Sensitivity of cancer cells to ionizing radiation (IR) is a critical factor in determining the efficacy of radiation therapy for cancer treatment (1). Intrinsic resistance to IR in some tumor types, such as pancreatic ductal adenocarcinoma (PDAC), contributes to treatment challenges (2). K-Ras activity is important in determining the response of many cancer cells to IR (3-8), particularly in PDAC, nearly all of which have oncogenically activating K-Ras mutations $(2,9)$. Therefore, understanding the molecular mechanisms by which K-Ras influences radiation sensitivity or resistance may ultimately improve therapeutic outcomes.

The roles of the two best-characterized Ras effectors, Raf serine/threonine kinases and phosphatidylinositol 3-kinases (PI3K) in radiation sensitivity have been analyzed in multiple cell types. In model epithelial cells, PI3K and Raf are both required for maximal H-Rasinduced radioresistance, although inhibition of these two molecules does not fully recapitulate inhibition $(10,11)$. Inhibitor studies in pancreatic and colorectal tumor-derived cell lines indicate that K-Ras can also cause radiation resistance via activation of epidermal growth factor (EGF) signaling, leading to H-Ras activation and signaling via PI3K $(12,13)$.

Ras binds and activates Ral-specific guanine nucleotide exchange factors (RalGEFs), which activate RalA and RalB (14-16). RalA and RalB are activated in PDAC cell lines and tumors, where they serve as critical regulators of proliferation and survival (17). Although RalA and RalB are $82 \%$ identical, and can interact with the same set of downstream effectors, they have distinct roles in cancer progression. While RalA is critical for anchorage-independent growth in vitro and tumorigenic growth in mice, RalB is essential for tumor cell invasion in vitro and metastasis in mice (18-21). Activation of RalA and RalB is sufficient for Ras-induced transformation of some human cell lines (22).

Ral proteins mediate their activities through multiple downstream effectors. Most notable are RalBP1/RLIP76, Exo84 and Sec5 (17). RalBP1 is a multifunctional protein that can function as a GAP for Rho family small GTPases (23). Interestingly, RalBP1 knockdown causes radiation sensitivity in mice following whole body irradiation (24). Exo84 and Sec5 are subunits of the exocyst, a multiprotein complex that directs certain secretory vesicles to specific plasma membrane areas (25). Although the mechanisms are unclear, Ral proteins appear to utilize the exocyst to regulate cell polarity and motility $(26,27)$, properties that are important to the transformed phenotype.

The importance of Ral proteins and their effectors for oncogenic growth has been revealed in the last ten years. To date, analysis of the role of Ras effectors in radiation responses has focused on the best studied effectors, Raf and PI3K. Our goal here was to determine if RalA or RalB also regulate cellular responses to IR.

\section{Methods and Materials \\ Expression Plasmids}

pSuperRetro shRNA expression constructs (puromycin ${ }^{\mathrm{r}}$ ) targeting RalA, RalB or a scramble control (Scr) were described previously (20). We used standard methods to generate (1) additional shRNA constructs (targeting K-Ras, RalA, RalB, Sec5 or GFP) in pSuperRetro (puromycin $^{\mathrm{r}}$ or blasticidin ${ }^{\mathrm{r}}$ ) and (2) constructs encoding shRNA-resistant variants of RalA 
or RalB in pBabe (puromycin ${ }^{\mathrm{r}}$ ). Clones for RalBP1 knockdown were purchased from Open Biosystems (RHS3979-9615119 and RHS3979-9615121).

\section{Cell Culture and Generation of Cell Lines}

MIA PaCa-2 and HEK293T cells were maintained in RPMI-1640 or DMEM-H (Invitrogen), respectively, supplemented with 5\% fetal bovine serum (FBS; Sigma) and antibiotics at $37^{\circ} \mathrm{C}$ and $5 \% \mathrm{CO}_{2}$. To generate stable knockdowns, retroviruses or lentiviruses were packaged in HEK293T cells. Cells were transfected with retroviral constructs and pVPack packaging vectors according to the manufacturer's instructions (Stratagene, La Jolla, CA), or with lentiviral constructs (Open Biosystems) and psPAX2 and pMD2.G packaging vectors (Addgene) according to the Addgene pLKO.1 protocol. Viruses were harvested and target cells infected according to above protocols.

\section{Antibodies/Western Blots}

Western blots were performed using standard protocols with mouse monoclonal antibodies as follows: RalA (BD Transduction Laboratories), RalB (Upstate), K-Ras (Calbiochem, OP24), $\beta$-actin (Sigma), $\gamma \mathrm{H} 2 \mathrm{AX}$ (Millipore), PARP (BD Pharmingen), RalBP1 (Abnova). Rabbit anti-Sec5 (28) was used at 1:2000. Secondary antibodies were HRP-conjugated sheep anti-mouse antibodies or donkey anti-rabbit (Amersham-Pharmacia). All antibodies were diluted according to manufacturers' recommendations using $1 \%$ bovine serum albumin in TBS-Tween 20. Antibodies were detected with Supersignal West Dura HRP chemiluminescent substrate (Pierce Biotechnology).

\section{Clonogenic Survival Assays}

MIA PaCa-2 cells stably expressing shRNAs were plated at low density. Approximately 18 $\mathrm{h}$ after plating, cells were irradiated with a single dose ( 2 Gy or $7 \mathrm{~Gy})$ from a Cs ${ }^{137}$ irradiator (JL Shepherd) at a rate of $150 \mathrm{cGy} / \mathrm{min}$. After two weeks, cells were fixed in methanol:acetic acid (3:1 v:v) and stained with $1 \%$ crystal violet. Colonies were counted manually using a threshold of 50 cells as a minimum for a viable colony. Plating efficiency and surviving fraction were calculated as described previously (10).

\section{Results}

To assess the role of Ral GTPases in the response of PDAC cells to IR, we utilized MIA $\mathrm{PaCa}-2$ cells, which exhibit K-Ras-dependent radioresistance, hyper-activation of Ral proteins, Ral dependent tumorigenic and metastatic growth $(9,19,20)$. We created cell lines with stable knockdown of RalA or RalB, utilizing previously published constructs to express shRNAs targeting each Ral protein (20). Constructs encoding shRNAs targeting K-Ras or a nonspecific (NS) sequence were used as positive and negative controls for radiosensitization, respectively. As expected, RalA-, RalB-, and K-Ras-targeting shRNAs produced specific knockdown of target protein expression (Figure 1A). We also observed that RalA expression was increased in RalB knockdown cells relative to control cells. This upregulation was reproducible and may represent a compensatory mechanism to deal with loss of RalB. Why a similar compensatory increase of RalB does not occur in RalA knockdown cells is unclear.

Post-IR survival was analyzed using standard clonogenic survival assays. Briefly, cells were plated, irradiated (Mock, 2 Gy or $7 \mathrm{~Gy}$ ) and allowed to grow for two weeks. Colonies were counted and surviving fractions (SF) calculated (Figure 1B; see Methods for details). As expected, K-Ras knockdown resulted in fewer colonies than NS control (SF2: $47.5 \%$ versus $78.9 \%, \mathrm{p}<0.01$; SF7: $2.6 \%$ versus $6.5 \%, \mathrm{p}<0.01$ ), indicating that loss of K-Ras sensitizes MIA PaCa-2 cells to IR. Knockdown of either RalA or RalB also resulted in significantly 
fewer colonies than NS control at 2 Gy (RalA: $S F 2=59.5 \%, p=0.02$; RalB: $\mathrm{SF} 2=59.2 \%$, $\mathrm{p}=0.01$ ) and $7 \mathrm{~Gy}$ (RalA: $\mathrm{SF} 7=4.1 \%, \mathrm{p}=0.02$; RalB: $\mathrm{SF} 7=3.8 \%, \mathrm{p}=0.01$ ), indicating that each Ral isoform contributes to reproductive survival in irradiated MIA PaCa-2 cells. As expected, K-Ras knockdown caused greater sensitization than knockdown of individual Ral isoforms, presumably because K-Ras drives additional effector pathways causing radioresistance $(1,12)$.

To confirm that radiosensitization was specific to Ral knockdowns, we introduced uncleavable variants of RalA or RalB into cells expressing each shRNA. Each construct restored protein expression to normal levels and rescued the clonogenic survival defects caused by shRNA expression (RalA shRNA SF2 $=58.4 \%$; RalA shRNA + Rescue SF2=73.7, $\mathrm{p}<0.01$ ) (RalA shRNA SF7 $=2.8 \%$; RalA shRNA + Rescue $S F 2=7.0, \mathrm{p}<0.01$ ) (RalB shRNA $\mathrm{SF} 2=28.3 \%$; RalB shRNA + Rescue SF2=59.7, p<0.01) (RalB shRNA SF7=2.7\%; RalB shRNA + Rescue $S F 2=5.3, p<0.01)$, indicating that the defects are specific to Ral knockdown (Figure 1C,D).

We also wished to ask if RalA and RalB act redundantly. We generated MIA PaCa-2 cells that stably expressed shRNAs targeting RalB and either RalA or NS control (Figure 2). We reasoned that if RalA and RalB act redundantly, RalA/RalB double knockdown cells would be significantly more sensitive to IR than single knockdowns. In fact, clonogenic survival of RalA/RalB double knockdown cells was not significantly different from that of RalB knockdown cells (SF2: NS/RalB $=62.4 \%$, RalA/RalB $=63.5 \%, \mathrm{p}=0.78 ; \mathrm{SF} 7: \mathrm{NS} / \mathrm{RalB}=4.3 \%$, $\mathrm{RalA} / \mathrm{RalB}=4.4 \%, \mathrm{p}=0.75$ ). Thus, $\mathrm{RalA}$ and $\mathrm{RalB}$ are each required for Ral pathway response to IR in MIA PaCa-2 cells.

We sought to understand the mechanisms whereby Ral knockdowns cause reduced survival post-IR. Radiation induces reactive oxygen species (ROS) that cause extensive DNA damage, particularly DSBs. If not repaired properly, DSBs lead to cell death (29). Thus, we quantified post-IR expression of phospho-H2AX ( $\gamma \mathrm{H} 2 \mathrm{AX})$, a marker of DSBs, in Ral knockdown cell lines (30). MIA PaCa-2 cells stably expressing RalA, RalB, or NS targeting sequences were exposed to IR, and $\gamma \mathrm{H} 2 \mathrm{AX}$ was detected by western blot analysis. Mock IR was used as a control to define baseline $\gamma \mathrm{H} 2 \mathrm{AX}$ expression. As expected, NS control cells showed a marked increase in $\gamma \mathrm{H} 2 \mathrm{AX} 1 \mathrm{~h}$ post-IR, which declined by $3 \mathrm{~h}$ post-IR, indicating efficient DSB repair (Figure 3). In contrast, MIA PaCa-2 cells with RalA or RalB knockdown maintained high levels of $\gamma \mathrm{H} 2 \mathrm{AX}$ expression $6 \mathrm{~h}$ post-IR, suggesting that DSBs are less efficiently repaired in MIA PaCa- 2 cells with Ral knockdowns.

When faced with irreparable damage, cells can undergo apoptosis to prevent proliferation. RalB is believed to contribute to tumor survival by inhibiting apoptosis (18). Therefore, we asked whether Ral knockdown altered caspase-dependent apoptosis, as measured by cleavage of PARP. Cell lysates were collected 24, 48 and 72 h post-IR (7 Gy) and PARP cleavage was assayed by western blot. As expected, NS control cells displayed elevated levels of cleaved PARP at 48 and $72 \mathrm{~h}$ post-IR. RalA knockdown did not significantly alter PARP cleavage, while RalB knockdown increased PARP cleavage by 24 h post-IR (earlier than control cells) and had higher levels of cleaved PARP relative to uncleaved (Figure 4). These results indicate that RalB, but not RalA, contributes to an anti-apoptotic survival function.

We next wished to determine which Ral effectors contribute to the Ral-dependent response to IR. We first analyzed RalBP1 (also known as RLIP76), a multi-domain protein required for protection against IR in C57BL/6 mice (24). MIA PaCa-2 cells expressing either of two distinct RalBP1-targeting shRNAs or a NS shRNA control were generated. Analysis of RalBP1 expression showed each shRNA caused greater than 95\% knockdown relative to NS 
control (Figure 5A). Contrary to previous mouse data, RalBP1 knockdown did not sensitize MIA PaCa-2 cells to IR (Figure 5B; SF2: NS shRNA=70.3\%, RalBP1 shRNA\#1=74.8\%, RalBP1 shRNA\#2=73.0\%; SF7: NS shRNA=6.0\%, RalBP1 shRNA\#1=5.8\%, RalBP1 shRNA\#2 $=6.3 \%$ ).

We next analyzed the role of Sec5, the other major Ral effector. Sec5 is a member of the exocyst complex that is critically involved in vesicle targeting and can also function downstream of RalB in cell survival, as RalB activation promotes Sec5 interaction with TBK1 kinase (31). We generated MIA-PaCa-2 cells stably expressing shRNAs targeting Sec5 and confirmed knockdown by western blot (Figure 6A). Sec5 knockdown did not sensitize MIA PaCa-2 cells to IR, suggesting that Ral-mediated post-IR survival does not act through Sec5 (Figure 6B; SF2: NS shRNA=71.8\%, Sec5 shRNA\#1=70.8 \%, Sec5 shRNA\#2 $=68.7 \%$; SF7: NS shRNA=7.7\%, Sec5 shRNA\#1=6.4 \%, RalBP1 shRNA\#2 $=7.5 \%$ ).

\section{Discussion}

Oncogenic Ras induces IR resistance in many tumor types, including pancreatic cancer, where over $90 \%$ of tumors carry oncogenic mutations in K-Ras. Recent work indicates that $\mathrm{K}$-Ras-mediated resistance to IR in pancreatic cancer cells is in part dependent upon the Ras effector PI3K (9), but does not require Raf (1). However, the role of the Ral small GTPases, which are also important Ras effectors, is unknown. As such, we focused our studies on Ral. We found that knockdown of either RalA or RalB sensitized MIA PaCa-2 cells to IR. Although RalA and RalB are 82\% identical, they have distinct functions in pancreatic cancer cells (20). Thus, it was perhaps unexpected that both RalA and RalB sensitized cells to IR. However, it appears that RalA and RalB do not function via completely overlapping mechanisms, as knockdown of both proteins simultaneously did not further increase sensitization.

The molecular mechanisms of Ras-regulated IR response are poorly understood. Rasinduced resistance has been proposed to function through modulation of cell cycle checkpoints, as oncogenic H-Ras causes resistance and prolongation of G2 phase in primary rat embryo cells (32-34). Additionally, oncogenic H-Ras expression enhances repair of gamma-, UV- and cisplatin-induced DNA damage in NIH 3 T3 cells $(35,36)$. The ability to repair DSBs is widely considered the most critical factor controlling IR sensitivity (37). As such, we used $\gamma \mathrm{H} 2 \mathrm{AX}$ as a marker of IR-induced DSBs. As expected, $\gamma \mathrm{H} 2 \mathrm{AX}$ expression increased shortly after IR regardless of Ral expression levels. In control cells, $\gamma \mathrm{H} 2 \mathrm{AX}$ levels declined by $3 \mathrm{~h}$ after IR while RalA and RalB knockdown resulted in high $\gamma \mathrm{H} 2 \mathrm{AX}$ levels for at least $6 \mathrm{~h}$. RalB knockdown resulted in a slightly weaker defect than did RalA knockdown. RalA upregulation in RalB knockdown cells may explain this difference. It would also be interesting to determine whether there are differential Ral isoform effects on S-phase distribution following radiation, which could further impact total cellular $\gamma \mathrm{H} 2 \mathrm{AX}$. To our knowledge, this is the first study to show a role for Ral proteins in repair of IR-induced DNA damage. Interestingly, in immortalized fibroblasts and an osteosarcoma-derived p53deficient cell line, oncogenic H-Ras also inhibits the G2-M checkpoint in a manner dependent on Ral proteins but not RalBP1 $(38,39)$. This is consistent with our findings that RalBP1 does not mediate Ral-dependent changes in IR responses in MIA PaCa-2 cells, which are also p53-deficient. Ral proteins also drive activation of cyclin D1 and cell cycle progression from G1-S in a RalBP1-independent manner (40). Thus, Ral proteins are involved in two distinct cell cycle checkpoints. It will be of interest in future studies to determine if modulation of these checkpoints is utilized by Ral to render cells radioresistant. 
Given previous reports indicating that RalB functions as an anti-apoptotic factor, we analyzed PARP cleavage to measure caspase-3-dependent apoptosis $(18,20)$. We found that control and RalA knockdown cells exhibited similar PARP cleavage kinetics post-IR. Since RalA knockdown decreases clonogenic survival and perturbs DSB resolution, we conclude that RalA likely contributes to cell death primarily via a caspase-independent mechanism, such as post-mitotic catastrophe (41). In constrast to control and RalA knockdown, RalB knockdown caused more rapid induction of apoptosis. This is consistent with published data indicating that RalB normally inhibits apoptosis (18). RalB engages Sec5, which in turn binds and activates TBK1 kinase to promote survival $(31,42)$. As Sec5 knockdown did not cause IR sensitivity, it is possible that RalB-dependent apoptosis is not a major contributor to IR sensitivity of MIA PaCa-2 cells. Alternatively, RalB-dependent apoptosis may occur via a Sec5-independent mechanism and constitute a significant component of IR sensitivity.

RalBP1 is a multi-domain protein with diverse functions $(17,43,44)$. It can protect cells by transporting toxic metabolites (45). RalBP1 is critical for IR response in mice and mouse embryonic fibroblasts $(24,46)$. Thus, RalBP1 was an excellent candidate for mediation of Ral-dependent IR resistance, and we were surprised that RalBP1 knockdown had no significant effect on clonogenic growth of MIA PaCa-2 cells post-IR. It is unlikely that knockdown was insufficient to reduce clonogenic survival in this context, since RalBP1 protein was reduced by $\sim 90 \%$. Instead, our findings likely differ from previous reports on RalPB1 due to differences in cell type or cell context. In future analyses, it will be interesting to see whether tumor type- or cell type-specific genetic alterations can predict a requirement for $\mathrm{Ral}$ in radiation responsiveness.

We next considered a Ral effector that is part of the exocyst, a protein complex involved in vesicle targeting. The exocyst is important for processes including establishing and maintaining cell polarity. It has been suggested that exocyst-induced polarity changes alter cell proliferation and survival (25). Ral directly regulates exocyst formation via interaction with two components, Sec5 and Exo84 (47). We thought it plausible that Ral proteins direct specific exocyst-mediated protein and membrane movements that control IR response. However, our clonogenic survival assays indicated that Sec5 knockdown does not alter IR response of MIA PaCa-2 cells.

Other Ral effectors have been identified, although their roles in oncogenesis remain poorly characterized. Although not a classical Ral effector pathway, in that interaction does not depend on GTP binding, Ral activation of phospholipase D1 (PLD1) has been implicated in cytokinesis and other cellular processes $(48,49)$. Ral proteins also transmit signals using ZONAB, a Y-box transcription factor that is regulated by association with Ral. ZONAB is unlikely to mediate Ral-dependent changes in IR sensitivity because the interaction between RalA and ZONAB occurs only when cells are grown at high density (50), whereas RalA and RalB knockdowns significantly alter IR response of cells grown in isolation.

In conclusion, our results indicate that both RalA and RalB make significant contribution to K-Ras dependent IR resistance of MIA PaCa-2 pancreatic cancer cells. Sensitization due to knockdown of RalA or RalB is, at least in part, due to decreased ability to repair DNA damage. RalB knockdown also may cause sensitization by increasing susceptibility to apoptosis. Neither canonical effector, RalBP1 nor Sec5, has a significant individual role in post-IR survival. Thus, it will be interesting to determine whether irradiation causes Ral proteins to engage atypical or novel effectors.

\section{Acknowledgments}

We thank Dr. Charles Yeaman (U. Iowa) for Sec5 antibody, Dr. Christopher Counter (Duke U.) for Ral shRNA and RalBP1 expression plasmids, and Dr. Elaine Zeman (UNC-CH) for helpful discussions. Our work was supported by 
grants from the NIH to ADC (CA109550) and to ADC and CJD (CA067771 and CA042978). ARK was supported by an NRSA postdoctoral fellowship (F32CA138142). ARK and JLS were supported by Lineberger

Comprehensive Cancer Center / NIH T32 postdoctoral fellowships. SFG was a Rutgers School of Medicine Fellow.

\section{References}

1. Gupta AK, Bakanauskas VJ, Cerniglia GJ, et al. The Ras radiation resistance pathway. Cancer Res 2001;61:4278-4282. [PubMed: 11358856]

2. Hezel AF, Kimmelman AC, Stanger BZ, et al. Genetics and biology of pancreatic ductal adenocarcinoma. Genes Dev 2006;20:1218-1249. [PubMed: 16702400]

3. Bernhard EJ, Mckenna WG, Hamilton AD, et al. Inhibiting Ras Prenylation Increases the Radiosensitivity of Human Tumor Cell Lines with Activating Mutations of ras Oncogenes. Cancer Res 1998;58:1754. [PubMed: 9563495]

4. Bernhard EJ, Stanbridge E, Gupta S, et al. Direct Evidence for the Contribution of Activated N-ras and K-ras Oncogenes to Increased Intrinsic Radiation Resistance in Human Tumor Cell Lines. Cancer Res 2000;60:6597. [PubMed: 11118040]

5. Kim IA, Fernandes AT, Gupta AK, et al. The influence of Ras pathway signaling on tumor radiosensitivity. Cancer Metastasis Rev 2004;23:227-236. [PubMed: 15197325]

6. McKenna WG, Muschel RJ. Targeting tumor cells by enhancing radiation sensitivity. Genes Chromosomes Cancer 2003;38:330-338. [PubMed: 14566853]

7. McKenna WG, Muschel RJ, Gupta AK, et al. The RAS signal transduction pathway and its role in radiation sensitivity. Oncogene 2003;22:5866-5875. [PubMed: 12947393]

8. Gupta AK, Bakanauskas VJ, McKenna WG, et al. Ras regulation of radioresistance in cell culture. Meth Enzymol 2001;333:284-290. [PubMed: 11400344]

9. Brunner TB, Cengel KA, Hahn SM, et al. Pancreatic cancer cell radiation survival and prenyltransferase inhibition: the role of K-Ras. Cancer Res 2005;65:8433-8441. [PubMed: 16166322]

10. Grana TM, Rusyn EV, Zhou H, et al. Ras mediates radioresistance through both phosphatidylinositol 3-kinase-dependent and Raf-dependent but mitogen-activated protein kinase/ extracellular signal-regulated kinase kinase-independent signaling pathways. Cancer Res 2002;62:4142-4150. [PubMed: 12124353]

11. Grana TM, Sartor CI, Cox AD. Epidermal growth factor receptor autocrine signaling in RIE-1 cells transformed by the Ras oncogene enhances radiation resistance. Cancer Res 2003;63:7807-7814. [PubMed: 14633707]

12. Cengel KA, Voong KR, Chandrasekaran S, et al. Oncogenic K-Ras signals through epidermal growth factor receptor and wild-type H-Ras to promote radiation survival in pancreatic and colorectal carcinoma cells. Neoplasia 2007;9:341-348. [PubMed: 17460778]

13. Toulany M, Dittmann K, Krüger M, et al. Radioresistance of K-Ras mutated human tumor cells is mediated through EGFR-dependent activation of PI3K-AKT pathway. Radiotherapy and Oncology 2005;76:143-150. [PubMed: 16024124]

14. Urano T, Emkey R, Feig LA. Ral-GTPases mediate a distinct downstream signaling pathway from Ras that facilitates cellular transformation. EMBO J 1996;15:810-816. [PubMed: 8631302]

15. White MA, Vale T, Camonis JH, et al. A role for the Ral guanine nucleotide dissociation stimulator in mediating Ras-induced transformation. J Biol Chem 1996;271:16439-16442. [PubMed: 8663585]

16. Wolthuis RM, Zwartkruis F, Moen TC, et al. Ras-dependent activation of the small GTPase Ral. Curr Biol 1998;8:471-474. [PubMed: 9550702]

17. Bodemann BO, White MA. Ral GTPases and cancer: linchpin support of the tumorigenic platform. Nat Rev Cancer 2008;8:133-140. [PubMed: 18219307]

18. Chien Y, White MA. RAL GTPases are linchpin modulators of human tumour-cell proliferation and survival. EMBO Rep 2003;4:800-806. [PubMed: 12856001]

19. Lim KH, Baines AT, Fiordalisi JJ, et al. Activation of RalA is critical for Ras-induced tumorigenesis of human cells. Cancer Cell 2005;7:533-545. [PubMed: 15950903] 
20. Lim KH, O'Hayer K, Adam SJ, et al. Divergent roles for RalA and RalB in malignant growth of human pancreatic carcinoma cells. Curr Biol 2006;16:2385-2394. [PubMed: 17174914]

21. Oxford G, Owens CR, Titus BJ, et al. RalA and RalB: antagonistic relatives in cancer cell migration. Cancer Res 2005;65:7111-7120. [PubMed: 16103060]

22. Hamad NM, Elconin JH, Karnoub AE, et al. Distinct requirements for Ras oncogenesis in human versus mouse cells. Genes Dev 2002;16:2045-2057. [PubMed: 12183360]

23. Jullien-Flores V, Dorseuil O, Romero F, et al. Bridging Ral GTPase to Rho pathways. RLIP76, a Ral effector with CDC42/Rac GTPase-activating protein activity. J Biol Chem 1995;270:2247322477. [PubMed: 7673236]

24. Awasthi S, Singhal SS, Yadav S, et al. RLIP76 is a major determinant of radiation sensitivity. Cancer Res 2005;65:6022-6028. [PubMed: 16024601]

25. Camonis JH, White MA. Ral GTPases: corrupting the exocyst in cancer cells. Trends Cell Biol 2005;15:327-332. [PubMed: 15953551]

26. Moskalenko S, Henry D, Rosse C, et al. The exocyst is a Ral effector complex. Nat Cell Biol 2002;4:66-72. [PubMed: 11740492]

27. Rossé C, Hatzoglou A, Parrini MC, et al. RalB mobilizes the exocyst to drive cell migration. Mol Cell Biol 2006;26:727-734. [PubMed: 16382162]

28. Gromley A, Yeaman C, Rosa J, et al. Centriolin anchoring of exocyst and SNARE complexes at the midbody is required for secretory-vesicle-mediated abscission. Cell 2005;123:75-87. [PubMed: 16213214]

29. Roos WP, Kaina B. DNA damage-induced cell death by apoptosis. Trends in molecular medicine 2006;12:440-450. [PubMed: 16899408]

30. Keogh MC, Kim JA, Downey M, et al. A phosphatase complex that dephosphorylates gammaH2AX regulates DNA damage checkpoint recovery. Nature 2006;439:497-501. [PubMed: 16299494]

31. Chien Y, White MA. Characterization of RalB-Sec5-TBK1 function in human oncogenesis. Meth Enzymol 2008;438:321-329. [PubMed: 18413258]

32. Cengel KA, McKenna WG. Molecular targets for altering radiosensitivity: lessons from Ras as a pre-clinical and clinical model. Crit Rev Oncol Hematol 2005;55:103-116. [PubMed: 16006139]

33. McKenna WG, Bernhard EJ, Markiewicz DA, et al. Regulation of radiation-induced apoptosis in oncogene-transfected fibroblasts: influence of H-ras on the G2 delay. Oncogene 1996;12:237-245. [PubMed: 8570201]

34. McKenna WG, Iliakis G, Weiss MC, et al. Increased G2 delay in radiation-resistant cells obtained by transformation of primary rat embryo cells with the oncogenes H-ras and v-myc. Radiat Res 1991;125:283-287. [PubMed: 2000452]

35. Cho HJ, Jeong HG, Lee JS, et al. Oncogenic H-Ras enhances DNA repair through the Ras/ phosphatidylinositol 3-kinase/Rac1 pathway in NIH3T3 cells. Evidence for association with reactive oxygen species. J Biol Chem 2002;277:19358-19366. [PubMed: 11884408]

36. Chang I, Youn C, Kim H, et al. Oncogenic H-Ras up-regulates expression of Ku80 to protect cells from gamma-ray irradiation in NIH3T3 cells. Cancer Res 2005;65:6811-6819. [PubMed: 16061663]

37. Khanna KK, Jackson SP. DNA double-strand breaks: signaling, repair and the cancer connection. Nat Genet 2001;27:247-254. [PubMed: 11242102]

38. Agapova LS, Ivanov AV, Sablina AA, et al. P53-dependent effects of RAS oncogene on chromosome stability and cell cycle checkpoints. Oncogene 1999;18:3135-3142. [PubMed: 10340385]

39. Agapova LS, Volodina JL, Chumakov PM, et al. Activation of Ras-Ral pathway attenuates p53independent DNA damage G2 checkpoint. J Biol Chem 2004;279:36382-36389. [PubMed: 15208305]

40. Henry DO, Moskalenko SA, Kaur KJ, et al. Ral GTPases contribute to regulation of cyclin D1 through activation of NF-kappaB. Mol Cell Biol 2000;20:8084-8092. [PubMed: 11027278]

41. Castedo M, Perfettini J-L, Roumier T, et al. Cell death by mitotic catastrophe: a molecular definition. Oncogene 2004;23:2825-2837. [PubMed: 15077146] 
42. Chien Y, Kim S, Bumeister R, et al. RalB GTPase-mediated activation of the IkappaB family kinase TBK1 couples innate immune signaling to tumor cell survival. Cell 2006;127:157-170. [PubMed: 17018283]

43. Feig LA, Urano T, Cantor S. Evidence for a Ras/Ral signaling cascade. Trends Biochem Sci 1996;21:438-441. [PubMed: 8987400]

44. Cantor SB, Urano T, Feig LA. Identification and characterization of Ral-binding protein 1, a potential downstream target of Ral GTPases. Mol Cell Biol 1995;15:4578-4584. [PubMed: 7623849]

45. Awasthi S, Sharma R, Yang Y, et al. Transport functions and physiological significance of $76 \mathrm{kDa}$ Ral-binding GTPase activating protein (RLIP76). Acta Biochim Pol 2002;49:855-867. [PubMed: 12545192]

46. Singhal SS, Yadav S, Singhal J, et al. Diminished drug transport and augmented radiation sensitivity caused by loss of RLIP76. FEBS Lett 2008;582:3408-3414. [PubMed: 18789326]

47. Moskalenko S, Tong C, Rosse C, et al. Ral GTPases regulate exocyst assembly through dual subunit interactions. J Biol Chem 2003;278:51743-51748. [PubMed: 14525976]

48. Cascone I, Selimoglu R, Ozdemir C, et al. Distinct roles of RalA and RalB in the progression of cytokinesis are supported by distinct RalGEFs. EMBO J. 2008

49. Jiang H, Luo JQ, Urano T, et al. Involvement of Ral GTPase in v-Src-induced phospholipase D activation. Nature 1995;378:409-412. [PubMed: 7477381]

50. Frankel P, Aronheim A, Kavanagh E, et al. RalA interacts with ZONAB in a cell densitydependent manner and regulates its transcriptional activity. EMBO J 2005;24:54-62. [PubMed: 15592429] 
A

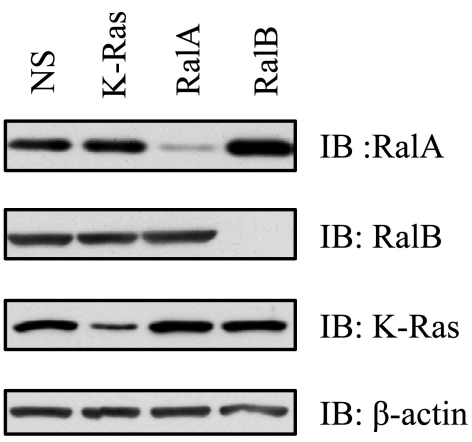

B

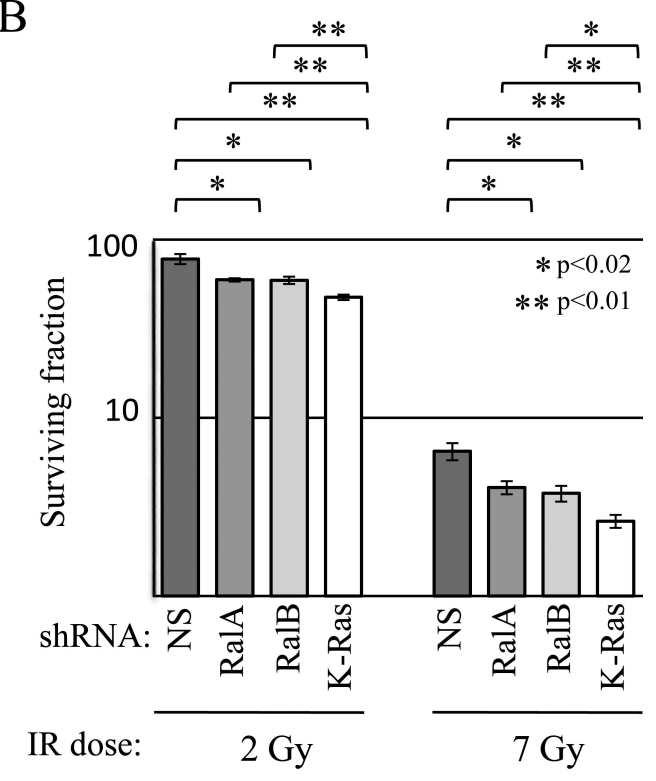

$\mathrm{D}$

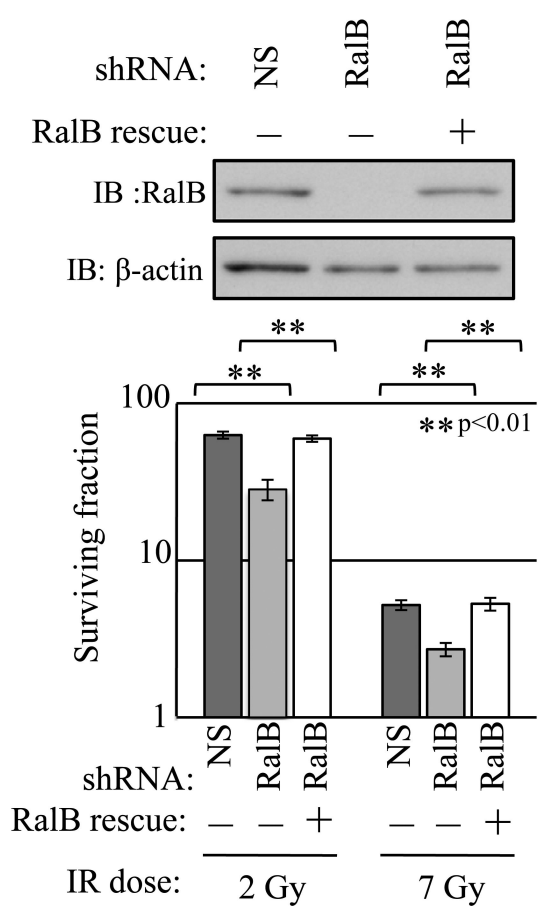

Figure 1. Knockdown of either RalA or RalB sensitizes MIA PaCa-2 pancreatic cancer cells to ionizing radiation (IR)

MIA PaCa-2 cells stably expressing shRNAs targeting RalA, RalB, K-Ras, or a non-specific sequence (NS) were generated. (a) Lysates were analyzed by immunoblotting (IB) to determine expression of RalA, RalB and K-Ras. $\beta$-actin was a loading control. Knockdowns of RalA, RalB and K-Ras were robust and specific. (b) Knockdown cells were analyzed by standard clonogenic growth assay following treatment with the indicated doses of IR. As expected, knockdown of K-Ras sensitized cells to IR. C Knockdown of either RalA or RalB also resulted in decreased survival post-IR. (c, d) shRNA-resistant ("rescue") versions of either RalA or RalB were stably expressed in cells expressing RalA or RalB shRNAs, 
respectively. (c) Top, RalA protein re-expression was confirmed by IB; bottom, RalA reexpression rescued clonogenic growth defects associated with RalA shRNA expression. (d) Top, RalB protein re-expression was confirmed by IB; bottom, RalB re-expression rescued clonogenic growth defects associated with RalB shRNA expression. All results shown are representative of at least three independent experiments. Clonogenic survival assays were performed at least three times in triplicate. Bars represent mean \pm standard deviation. 


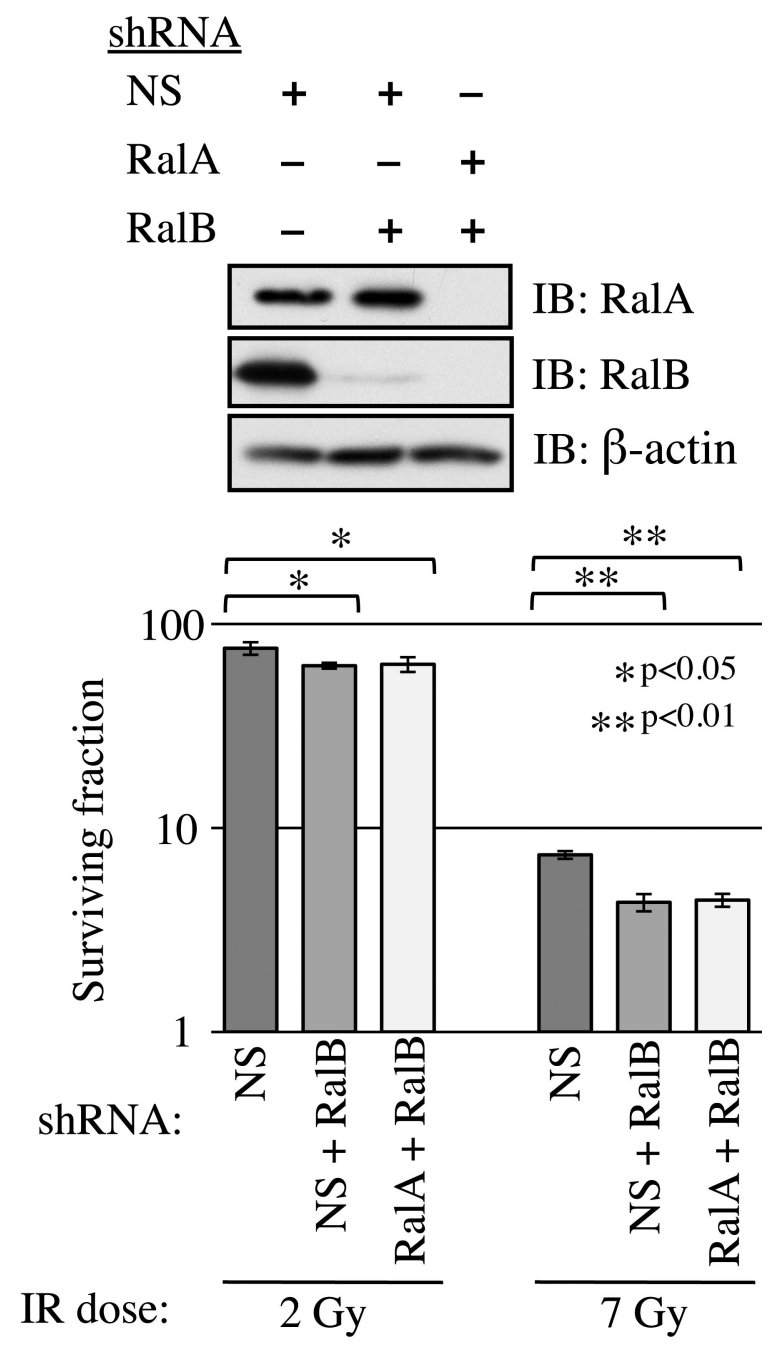

Figure 2. RalA/B double knockdowns do not further sensitize MIA PaCa-2 cells to IR MIA PaCa-2 cells simultaneously and stably expressing shRNAs targeting RalA and RalB or NS and RalB were generated. Top, cells were analyzed by IB to confirm knockdown. Bottom, clonogenic growth assay indicates that knockdown of both Ral proteins did not result in an additional decrease in post-IR survival compared to knockdown of either protein alone. Clonogenic survival assays were performed at least three times in triplicate. Bars represent mean \pm standard deviation. 


\begin{tabular}{|c|c|c|c|c|c|c|c|c|c|c|c|c|}
\hline \multirow[b]{2}{*}{$\mathrm{h}$ post-IR } & \multicolumn{4}{|c|}{ NS shRNA } & \multicolumn{4}{|c|}{ RalA shRNA } & \multicolumn{4}{|c|}{ RalB shRNA } \\
\hline & 0 & 1 & 3 & 6 & 0 & 1 & 3 & 6 & 0 & 1 & 3 & 6 \\
\hline IB: $\gamma \mathrm{H} 2 \mathrm{AX}$ & - & $=$ & 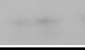 & 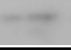 & 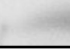 & & & & 4 & $=$ & - & - \\
\hline IB: $\beta$-actin & $=$ & $=$ & $=$ & - & & 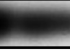 & & & - & $=$ & $-\infty$ & - \\
\hline elative $\gamma \mathrm{H} 2 \mathrm{AX}$ & 1.0 & 31.4 & 0.57 & 1.9 & 1.0 & 68.2 & 68.6 & 96.2 & 1.0 & 19.4 & 38.9 & 68.7 \\
\hline
\end{tabular}

Figure 3. Loss of either RalA or RalB increases persistence of the DSB marker $\gamma \mathrm{H} 2 \mathrm{AX}$ $\gamma \mathrm{H} 2 \mathrm{AX}$ expression was used as a marker of DSB. Top panels, Immunoblot analysis of $\gamma \mathrm{H} 2 \mathrm{AX}$ levels at indicated times after administration of IR (7 Gy). Bottom panels, immunoblot analysis of the loading control, $\beta$-actin. Relative $\gamma \mathrm{H} 2 \mathrm{AX}$ expression was quantified by densitometry of immunoblots and normalized to $\beta$-actin. In cells in which RalA or RalB expression had been knocked down, $\gamma \mathrm{H} 2 \mathrm{AX}$ expression remained elevated at time points after it was restored to background levels in control (NS) cells. 


\author{
shRNA: NS RalA RalB \\ $\begin{array}{llllllllllll}\text { M } & 24 & 48 & 72 & \text { M } & 24 & 48 & 72 & \text { M } & 24 & 48 & 72\end{array}$ \\ IB: PARP

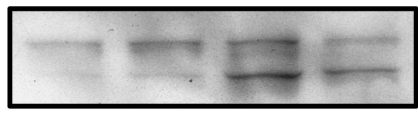 \\ IB: $\beta$-actin

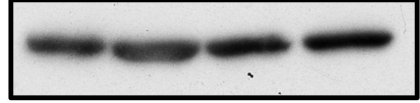 \\ \begin{tabular}{ll|l|l|l} 
\% cleaved PARP & 17 & 7 & 64 & 84
\end{tabular}

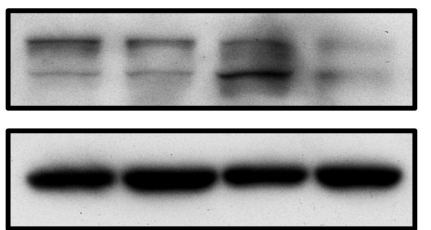 \\ $\begin{array}{llll}19 & 22 & 79 & 70\end{array}$
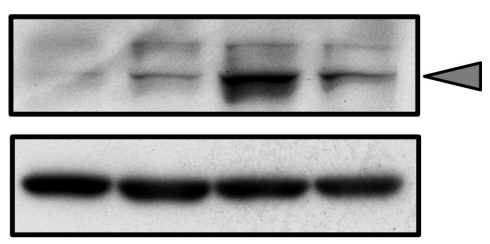 \\ $23 \quad 55 \quad 9796$ \\ Figure 4. Loss of RalB but not RalA sensitizes MIA PaCa-2 cells to IR-induced apoptosis \\ Poly (ADP-ribose) polymerase (PARP) cleavage was used to determine if IR-induced \\ apoptotic cell death is altered by RalA or RalB knockdown. Cells were irradiated with 7 Gy \\ and lysates were collected at the indicated time points (in hours) or after mock irradiation \\ (M). Top panels show immunoblots probing for PARP. Cleaved PARP is marked by a grey \\ arrowhead. Bottom panels show immunoblots of $\beta$-actin loading control. In control (NS) and \\ RalA knockdown cells, PARP cleavage at $24 \mathrm{~h}$ was similar to mock (M), with most PARP \\ cleaved by 48 h. By contrast, in RalB knockdown cells a majority of PARP was cleaved \\ after only $24 \mathrm{~h}$.
}


A
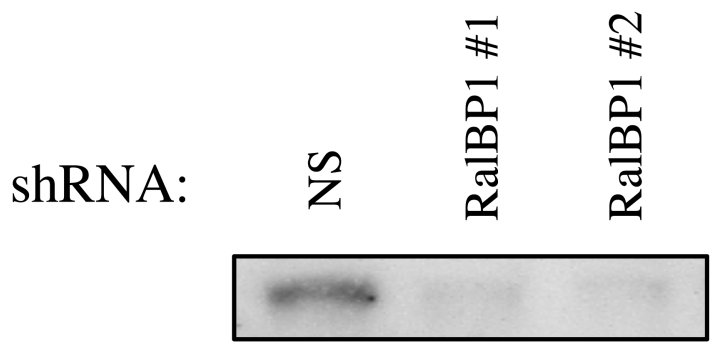

IB: RalBP1

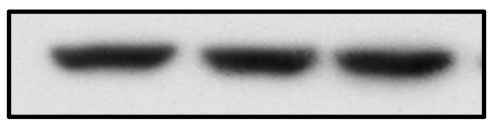

IB: $\beta$-actin

B

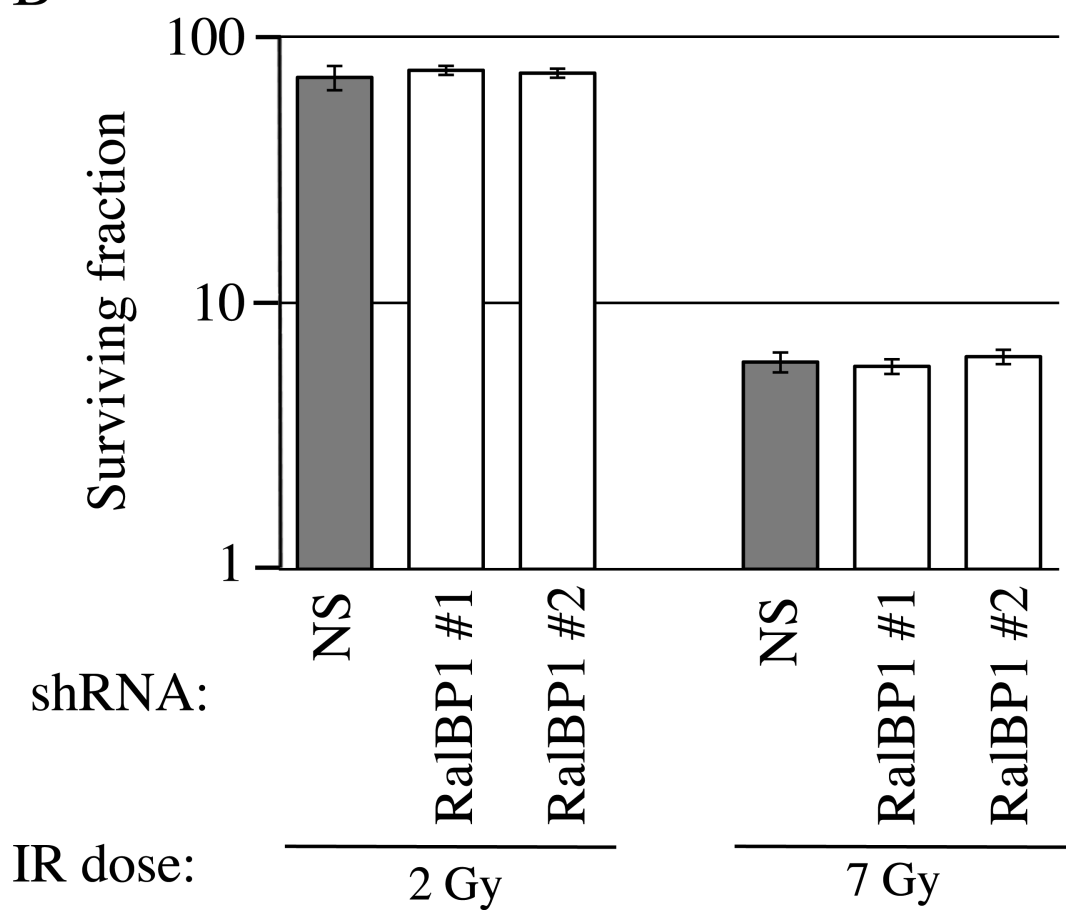

Figure 5. Radiosensitivity due to loss of RalA or RalB is not mediated by the canonical Ral effector RalBP1

(a) Lysates from cells expressing the indicated shRNAs were analyzed by immunoblot (IB) to confirm RalBP1 knockdown. (b) Cells with each protein knocked down were analyzed by clonogenic growth assay. Unexpectedly, knockdown of RalBP1 did not alter colony formation. Clonogenic survival assays were performed at least three times in triplicate. Bars represent mean \pm standard deviation. 


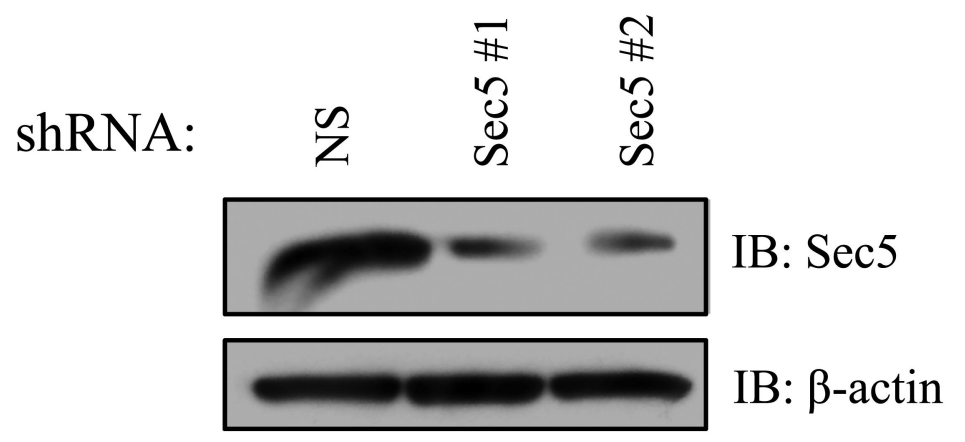

$\mathrm{B}$

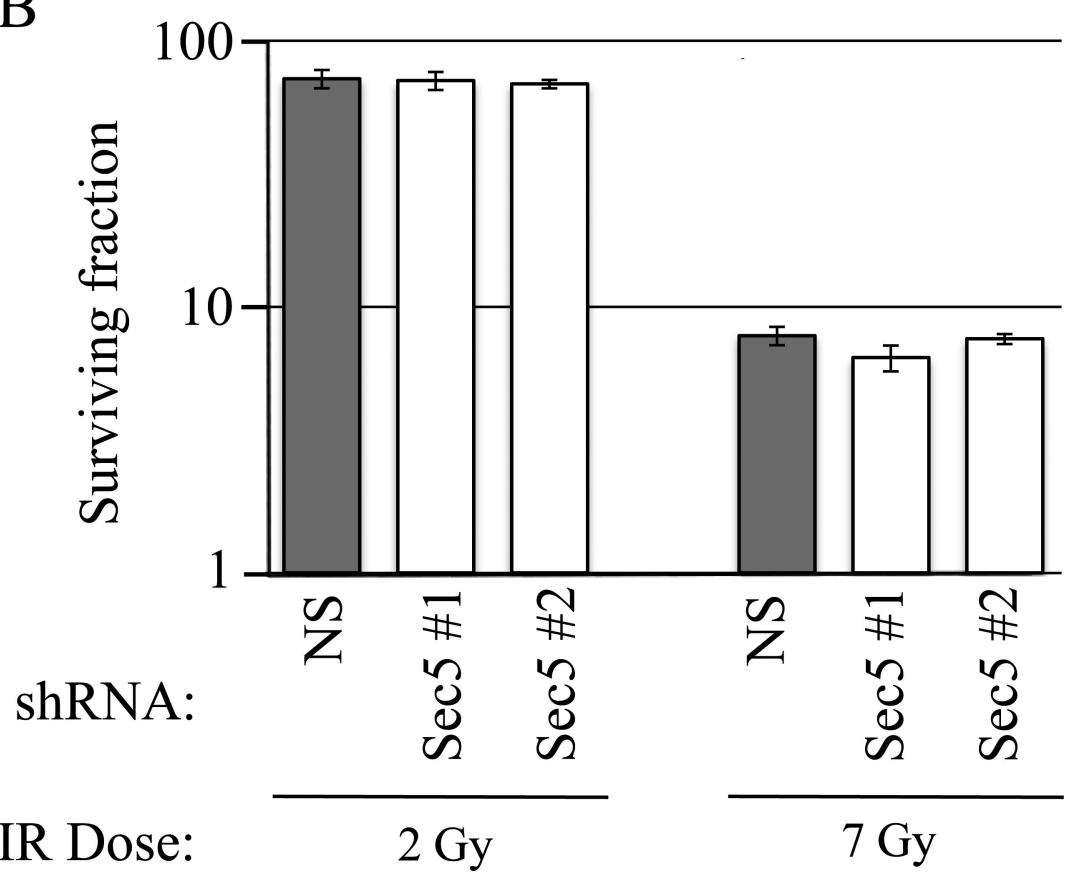

Figure 6. Radiosensitivity due to loss of RalA or RalB is not mediated by the exocyst component Sec5

(a) Lysates from cells expressing the indicated shRNAs were analyzed by immunoblot (IB) to confirm Sec5 knockdown. (b) Cells with each protein knocked down were analyzed by clonogenic growth assay. Knockdown of Sec5 did not alter colony formation. Clonogenic survival assays were performed at least three times in triplicate. Bars represent mean \pm standard deviation. 